\title{
Topical treatment of contact dermatitis by pine processionary caterpillar
}

\author{
Pedro Cuevas, ${ }^{1}$ Javier Angulo, ${ }^{1}$ Guillermo Giménez-Gallego² \\ ${ }^{1}$ Research Department, Hospital Ramon y Cajal, Madrid, Spain; \\ 2Departamento de Estructura y Función de Proteínas, Centro de Investigaciones Biológicas (CSIC), Madrid, Spain
}

Correspondence to Professor Pedro Cuevas, pedro.cuevas@hrc.es

\section{Summary}

Skin contact dermatitis by pine processionary (Thaumetopoea pityocampa) is a public health problem of increasing significance. The authors present here the case of a 65-year-old man who was diagnosed with processionary caterpillar dermatitis. Patient was treated with topical potassium dobesilate $5 \%$ cream twice a day for 2 days. An improvement occurred soon after treatment.

\section{BACKGROUND}

We report here a new unpublished treatment for dermatitis, due to contact with pine processionary caterpillar. This treatment, contrarily to those actually used, shows a prompt satisfactory response without secondary effects.

\section{CASE PRESENTATION}

A 65-year-old man presented with complaints of pruritus in both forearms. He had come in contact with pine processionary caterpillars. A clinical diagnosis of contact dermatitis secondary to contact with pine processionary caterpillars was made. Cutaneous examination revealed erithematous plaques formed by the confluence of diffuse urticariform papules (figure 1A). Three h after exposure to caterpillars, a potassium dobesilate $5 \%$ cream prepared as previously reported ${ }^{1}$ at the pharmacy department of the Hospital Universitario Ramón y Cajal in Madrid, Spain, was self-applied by the patient twice a day for 2 days. After 1 day of treatment, skin lesions decreased and pruritus disappeared. A near complete disappearance of erithematous plaques was observed at 2 days of treatment (figure 1B). Three weeks later, the patient reported that complete resolution of skin lesions remained without further clinical manifestation or drug-related side effect.

\section{TREATMENT}

This is the first case demonstrating the efficiency of using topical application of potassium dobesilate $5 \%$ cream, a specific inhibitor of fibroblast growth factor (FGF) in contact dermatitis.

\section{DISCUSSION}

Skin contact with pine processionary carterpillars is a public health problem of increasing significance that causes dermatitis usually located in exposed areas. Recently the existence of an immediate hypersensitivity mechanism has been demonstrated, mainly in occupationally exposed people. ${ }^{2}$ Systemic symptoms, such as vomiting, abdominal pain, hypertension or anaphylaxis have only rarely been reported. The skin histology of caterpillar exposure typically shows epidermal oedema, superficial perivascular lymphocytic infiltrate and eosinophils. ${ }^{3}$ Eczematous reactions are typically treated with mild-to high topical steroids. However, response to topical steroids is often ineffective. ${ }^{4}$ Urticarial reactions may be treated with oral antihistaminics but a number of reports document the failure of antihistaminics to relieve itch. ${ }^{4}$ However, these standard treatments are maintained at least for 1 week.

Activated endothelial cells are critically involved in the pathogenesis of inflammation which is characterised by vasopermeability, plasma leakage and leucocyte recruitment. Therefore, inhibitors of activated vascular endothelium could reduce inflammation. ${ }^{5}$ Acute dermal plasma leakage after processionary contact contributes to oedema formation. 6 Vascular endothelial growth factor (VEGF) is 10000 times more potent than histamine for inducing skin plasma leakage. In dermatitis, production of VEGF is increased. VEGF acts as a proangiogenic factor and induces hyperpermeavility of blood vessels, and several reports have suggested that inhibition of its production or blockade of its activity may be an effective new therapeutic strategy for treating dermatitis. ${ }^{7}$ Recently, we have reported that dihydroxyphenylsulfonate (dobesilate; Doxium) inhibits acute VEGF-induced plasma leakage in rats $^{8}$. Thus, the rapid effect of topical application of dobesilate against contact caterpillar dermatitis could be explained by its inhibitory effects on VEGF which is upregulated in dermatitis ${ }^{9-11}$. On the other hand, accumulating experimental evidence supports a role of FGF in inflammation ${ }^{12-15}$. In this case report we evaluated the effects of dobesilate, which is also a new well-characterised and efficient synthetic FGF inhibitor, ${ }^{16}$ on inflammation induced by contact hypersensitivity reactions to pine processionary caterpillars. The early application of the treatment could contribute to the rapid effects of dobesilate but it should be also considered that, as mentioned above, dobesilate has been shown to inhibit acute events in skin inflammation such as vascular permeability. ${ }^{8}$ As far as we know, there are no reports on caterpillar contact dermatitis treated with topical dobesilate. Our patient showed a good and prompt response to treatment 


\section{BMJ Case Reports}
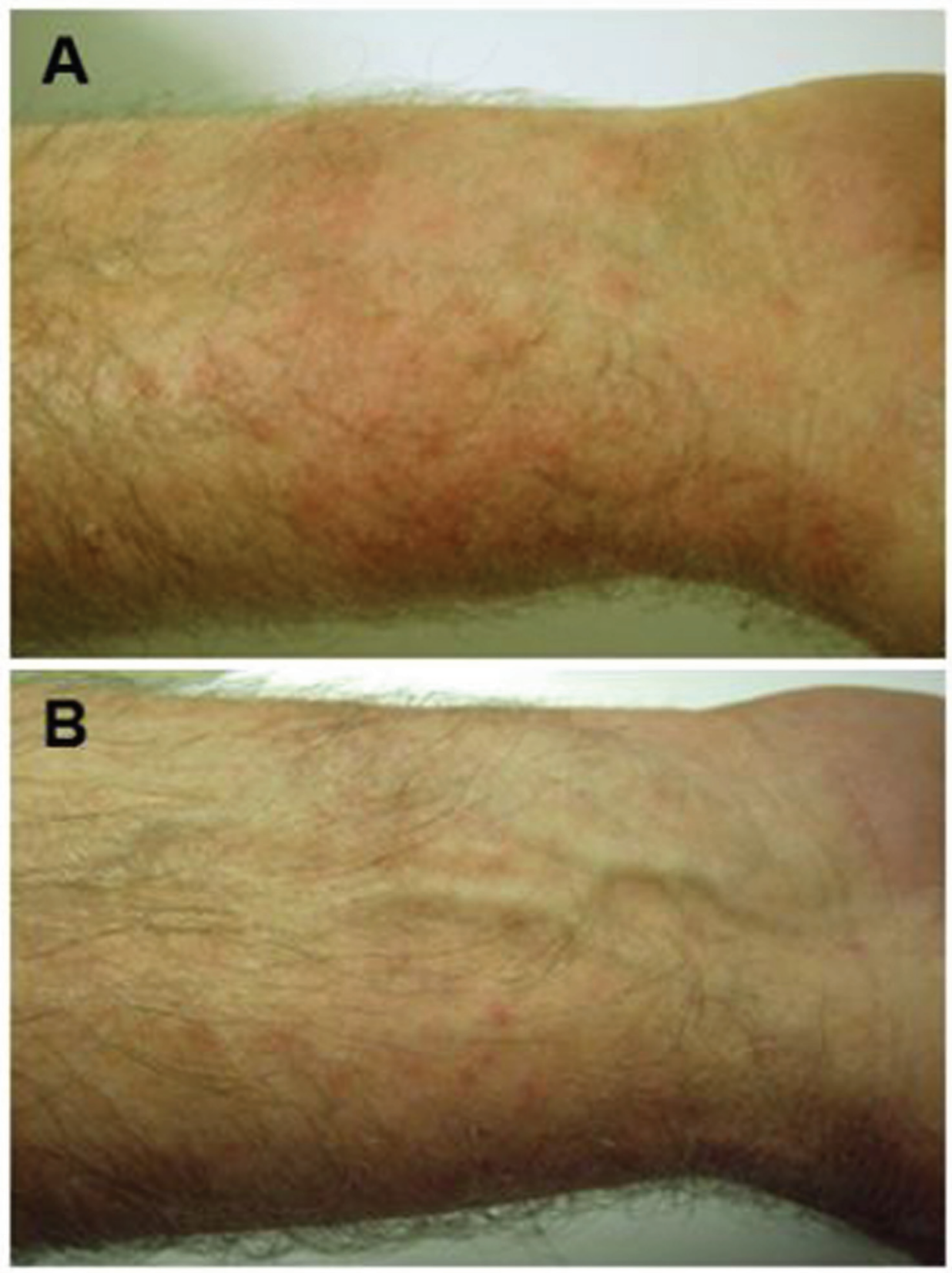

Figure 1 Improvement of contact dermatitis due to pine processionary caterpillars. An improvement of erithematous lesions was observed as early as 2 days after dobesilate topical application (B) compared to baseline conditions (A).

suggesting that topically applied dobesilate is of help in contact dermatitis.

\section{Learning points}

- Exposure to pine caterpillar causes contact dermatitis with oedema and leucocyte infiltration.

- VEGF contributes to vascular hyperpermeability in dermatitis while FGF is also involved in skin inflammatory process.

- Dobesilate inhibits VEGF- and FGF-induced activities.

- Topical application of dobesilate rapidly resolves dermatitis caused by caterpillar contact.
Acknowledgements Authors are grateful to Covadonga Perez from the pharmacy department at the Hospital Universitario Ramón y Cajal for preparing the dobesilate cream used in patient treatment.

Competing interests None.

Patient consent Obtained.

\section{REFERENCES}

1. Cuevas $\mathbf{P}$, Calvo $\mathrm{M}$, Angulo J, et al. Efficacy of the fibroblast growth factor inhibitor 2,5-dihydroxyphenylsulfonate in basal cell carcinoma: a histopathological and inmunohistochemical study. J Dermatolog Treat 2011; (in press).

2. Vega J, Vega JM, Moneo I, et al. Occupational immunologic contact urticaria from pine processionary caterpillar (Thaumetopoea pityocampa): experience in 30 cases. Contact Derm 2004;50:60-4.

3. Utikal J, Booken N, Peitsch WK, et al. [Caterpillar dermatitis. An increasing dermatologic problem in warmer regions of Germany]. Hautarzt 2009;60:48-50. 
4. Hossler EW. Caterpillars and moths: part II. Dermatologic manifestations of encounters with Lepidoptera. J Am Acad Dermatol 2010;62:13-28; quiz 29-30.

5. Velasco P, Huegel R, Brasch J, et al. The angiogenesis inhibitor thrombospondin-1 inhibits acute cutaneous hypersensitivity reactions. J Invest Dermatol 2009;129:2022-30.

6. Inal A, Altinta DU, Güvenmez HK, et al. Life-threatening facial edema due to pine caterpillar mimicking an allergic event. Allergol Immunopathol (Madr) 2006; 34:171-3.

7. Zhang Y, Matsuo H, Morita E. Increased production of vascular endothelia growth factor in the lesions of atopic dermatitis. Arch Dermatol Res 2006:297:425-9.

8. Angulo J, Peiró C, Romacho T, et al. Inhibition of vascular endothelial growth factor (VEGF)-induced endothelial proliferation, arterial relaxation, vascular permeability and angiogenesis by dobesilate. Eur J Pharmacol 2011; (in press).

9. Watanabe H, Mamelak AJ, Wang B, et al. Anti-vascular endothelial growth factor receptor-2 (Flk-1/KDR) antibody suppresses contact hypersensitivity. Exp Dermatol 2004;13:671-81.

10. Bae CJ, Shim SB, Jee SW, et al. IL-6, VEGF, KC and RANTES are a major cause of a high irritant dermatitis to phthalic anhydride in C57BL/6 inbred mice. Allergol Int 2010;59:389-97.
11. Zedan H, Abd El-Baset HA, Abd-Elsayed AA, et al. Lesional skin vascular endothelial growth factor levels correlate with clinical severity in patients with cement allergic contact dermatitis. East Mediterr Health J 2010;16:420-4.

12. Wempe $\mathbf{F}$, Lindner V, Augustin HG. Basic fibroblast growth factor (bFGF) regulates the expression of the CC chemokine monocyte chemoattractant protein-1 (MCP-1) in autocrine-activated endothelial cells. Arterioscler Thromb Vasc Biol 1997:17:2471-8.

13. Zittermann SI, Issekutz AC. Basic fibroblast growth factor (bFGF, FGF-2) potentiates leukocyte recruitment to inflammation by enhancing endothelial adhesion molecule expression. Am J Pathol 2006;168:835-46.

14. Tsunoda S, Sakurai H, Saito Y, et al. Massive T-lymphocyte infiltration into the host stroma is essential for fibroblast growth factor-2-promoted growth and metastasis of mammary tumors via neovascular stability. Am J Pathol 2009;174:671-83.

15. Huang JJ, Joh JW, Fuentebella J, et al. Eotaxin and FGF enhance signaling through an extracellular signal-related kinase (ERK)-dependent pathway in the pathogenesis of Eosinophilic esophagitis. Allergy Asthma Clin Immunol 2010;6:25.

16. Fernández IS, Cuevas P, Angulo J, et al. Gentisic acid, a compound associated with plant defense and a metabolite of aspirin, heads a new class of in vivo fibroblast growth factor inhibitors. J Biol Chem 2010;285:11714-29.

This pdf has been created automatically from the final edited text and images.

Copyright 2011 BMJ Publishing Group. All rights reserved. For permission to reuse any of this content visit http://group.bmj.com/group/rights-licensing/permissions.

BMJ Case Report Fellows may re-use this article for personal use and teaching without any further permission.

Please cite this article as follows (you will need to access the article online to obtain the date of publication).

Cuevas P, Angulo J, Giménez-Gallego G. Topical treatment of contact dermatitis by pine processionary caterpillar. BMJ Case Reports 2011;

10.1136/bcr.06.2011.4351, date of publication

Become a Fellow of BMJ Case Reports today and you can:

- Submit as many cases as you like

- Enjoy fast sympathetic peer review and rapid publication of accepted articles

- Access all the published articles

- Re-use any of the published material for personal use and teaching without further permission

For information on Institutional Fellowships contact consortiasales@bmjgroup.com

Visit casereports.bmj.com for more articles like this and to become a Fellow 